\title{
PENGARUH KUALITAS PRODUK TERHADAP KEPUASAN KONSUMEN MEMBELI HELM GM DI KOTA PALU
}

\author{
Refly Chrismariyanto \\ Rosida P. Adam \\ Farid \\ Program Studi S1 Jurusan Manajemen Fakultas Ekonomi dan Bisnis, Universitas Tadulako \\ Email: reflychris@gmail.com;rosida_adam@yahoo.co.id;faridmnj45@gmail.com;
}

\begin{abstract}
The purpose of this study is to determine whether product quality consisting of performance, characteristics, reliability, durability, usability, response, beauty, and reputation simultaneously and partially has a significant effect on customer satisfaction buying GM helmets in Palu City. This research is a causal descriptive study. Data obtained directly from the questionnaire results from 90 respondents who use GM helmets in the city of Palu. The analytical method in this research is multiple linear regression analysis. The results showed that the product quality variable consisting of performance, characteristics, reliability, durability, usability, response, beauty, and reputation simultaneously had a significant effect on customer satisfaction buying GM helmets in Palu City.
\end{abstract}

Keywords: Product Quality, Satisfaction

\begin{abstract}
Abstrak
Tujuan penelitian ini adalah mengetahui apakah kualitas produk yang terdiri dari kinerja, ciri khas, keandalan, ketahanan, daya guna, tanggapan, keindahan, dan reputasi secara simultan dan parsial berpengaruh signifikan terhadap kepuasan konsumen membeli helm GM di Kota Palu. Penelitian ini merupakan penelitian deskriptif kausal. Data diperoleh secara langsung dari hasil kuesioner dari 90 responden yang menggunakan helm GM di Kota Palu. Metode analisis dalam penelitian ini adalah analisis regresi linear berganda. Hasil penelitian menunjukkan bahwa variabel kualitas produk yang terdiri terdiri dari kinerja, ciri khas, keandalan, ketahanan, daya guna, tanggapan, keindahan, dan reputasi secara simultan berpengaruh signifikan terhadap kepuasan konsumen. Kinerja, ciri khas, keandalan, ketahanan, daya guna, tanggapan, keindahan, dan reputasi berpengaruh signifikan terhadap kepuasan konsumen membeli helm GM di Kota Palu.
\end{abstract}

Kata Kunci : Kualitas Produk, Kepuasan

\section{PENDAHULUAN}

Persaingan bisnis dalam era globalisasi dewasa ini sangat ketat, di mana setiap perusahaan harus dapat memenuhi kebutuhan konsumen, mempunyai keunggulan dan menciptakan produk yang berbeda dengan pesaing. Kotler dan Keller (2009:5) mengatakan para manajer pemasaran harus memutuskan fitur apa yang harus diciptakan pada produk, harga yang ditawarkan kepada pelanggan, dimana mereka harus menjual produk, dan berapa jumlah anggaran yang harus dihabiskan untuk iklan, penjualan, atau internet.

Fenomena dalam industri sepeda motor, ternyata industri otomotif khususnya sepeda motor tak pernah mengenal krisis. Pertumbuhan yang sangat pesat tentu saja menimbulkan dampak baik positif maupun dampak negatif, dampak negatifnya banyaknya persoalan keamanan, ketertiban, kelancaran dan keselamatan lalu lintas, dampak positifnya menjadi peluang bisnis untuk para pengusaha dengan meningkatnya penjualan sepeda motor maka peningkatan perlengkapannya menjadi meningkat, seperti helm, jaket, sarung tangan dan sepatu. Helm yang baik adalah helm yang aman dan nyaman, helm semacam ini lulus persyaratan Departement of Transportation (DOT) atau standar transportasi Amerika 
Serikat, serta standar-standar lain seperti untuk Eropa, Jepang, dan Indonesia sendiri harus memiliki label Standar Nasional Indonesia (SNI).

Semakin berkualitas produk yang ditawarkan oleh perusahaan maka kepuasan yang dirasakan oleh pelanggan akan semakin tinggi, di Kota Palu minat beli konsumen terhadap helm GM lebih tinggi dibandingkan dengan merek helm lainnya, itu membuktikan bahwa helm merek GM lebih berkualitas dibandingkan merek helm lainnya. Perusahaan yang menghasilkan suatu produk atau jasa yang berkualitas akan mendapat predikat sebagai organisasi yang mengutamakan kualitas. Karena produk yang dihasilkan sesuai dengan kebutuhan dan harapan pelanggan, selain itu dengan diterapkannya quality control yang ketat perusahaan akan terhindar dari kegiatan yang tidak menghasilkan produk atau jasa yang tidak dibutuhkan oleh pelanggan.

\section{KAJIAN LITERATUR DAN KERANGKA PEMIKIRAN}

Produk yang ditawarkan perusahaan akan berpengaruh terhadap kegiatan perusahaan mulai dari mendesain, sistem produksi dan operasi, menciptakan program pemasaran, sistem distribusi, iklan dan mengarahkan tenaga penjual. Menurut Kotler dan Keller (2009:4) produk adalah segala sesuatu yang dapat ditawarkan kepada pasar untuk memuaskan suatu keinginan atau kebutuhan, termasuk barang fisik, jasa, pengalaman, acara, orang, tempat, properti, organisasi, informasi, dan ide.

Menurut Shandy at all (2014) produk merupakan segala sesuatu yang dapat ditawarkan produsen untuk diperhatikan, diminta, dicari, dibeli, digunakan atau dikonsumsi pasar sebagai pemenuhan kebutuhan atau keinginan pasar yang bersangkutan. Menurut Harman (2017:31) produk adalah suatu barang nyata yang dapat terlihat atau berwujud dan bahkan dapat dipegang yang dirancang untuk memuaskan keinginan atau kebutuhan konsumen seperti komputer, mobil, pasta gigi, makanan dan lainlain. Menurut Buchari (2014:139) produk itu bukan hanya berbentuk sesuatu yang berwujud saja, seperti makanan, pakaian, dan sebagainya, akan tetapi juga sesuatu yang tidak berwujud seperti pelayanan jasa. konsep pemasaran memulai dari product, price, place, dan promotion. Pemasar sebaiknya memiliki pengetahuan dalam konsep dan prinsip pemasaran agar kegiatan pemasaran dapat tercapai sesuai dengan kebutuhan dan keinginan manusia terutama pihak konsumen yang dituju.

Kualitas produk memiliki keterkaitan erat dengan kepuasan konsumen kualitas memberikan suatu dorongan kepada konsumen untuk menjalin ikatan yang kuat dengan perusahaan, ikatan menginginkan perusahaan untuk memahami dengan seksama harapan konsumen serta kebutuhan mereka. Menurut Mariana (2015) kualitas yang baik maupun pelayanan merupakan hal yang perlu mendapatkan perhatian utama dari sebuah perusahaan, mengingat kualitas berkaitan erat dengan masalah kepuasan konsumen yang merupakan tujuan dari kegiatan pemasaran yang dilakukan oleh sebuah perusahaan. Menurut Ndaru Prasastono dan Sri Yulianto (2012) kualitas produk adalah suatu cara perusahaan untuk memberikan kepada konsumen, memenuhi apa saja yang diinginkan atau dikehendaki oleh konsumen tersebut.

Menurut Kotler dan Keler (2009:330) kebanyakan produk disediakan pada satu diantara empat tingkatan kualitas yaitu: kualitas rendah, kualitas rata-rata sedang, kualitas baik dan kualitas sangat baik. Beberapa dari atribut diatas dapat diukur secara objektif, namun dari sudut pemasaran kualitas harus diukur dari sisi persepsi pembeli tentang kualitas produk tersebut. Assuari (2004) mengatakan bahwa kualitas produk merupakan faktor-faktor yang terdapat dalam suatu barang atau hasil yang menyebabkan barang atau hasil tersebut sesuai dengan tujuan untuk apa barang atau hasil itu dimaksudkan.

Kualitas produk merupakan hal penting yang harus diusahakan oleh setiap perusahaan apabila menginginkan produk yang dihasilkan dapat bersaing di pasar, konsumen selalu ingin mendapatkan produk yang berkualitas sesuai dengan harga yang dibayar. Apabila hal itu dilaksanakan oleh perusahaan, maka perusahaan tersebut akan dapat tetap memuaskan para konsumen dan dapat menambah jumlah konsumen, dalam perkembangan suatu perusahaan, kualitas produk menentukan tingkat penjualan perusahaan tersebut. 


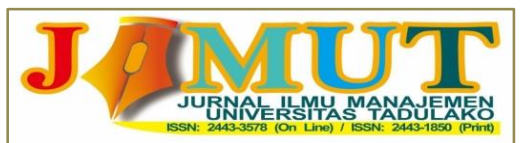

Vol. 6, No.3, September 2020, 232-242

Mutu atau kualitas produk dapat dicapai dengan memperhatikan delapan dimensi mutu Sistaningrum (2002:13) berikut ini:

1. Kinerja, merupakan karakteristik utama yang melekat pada produk (barang atau jasa).

2. Ciri khas (features), merupakan sentuhan tambahan, karakteristik yang kedua pada produk.

3. Keandalan (reability), merupakan konsistensi dan performa sepanjang waktu.

4. Ketahanan (durability), merupakan masa manfaat dari suatu produk.

5. Daya guna (service ability), merupakan penyelesaian masalah dan keluhan.

6. Tanggapan (response), merupakan karakteristik kecocokan konsumen terhadap ketepatan waktu, kesopanan, profesional, dan sebagainya.

7. Keindahan (esthetice), merupakan karakteristik produk yang berhubungan dengan panca indra yang dapat dilihat, diraba, dirasa, maupun diteliti.

8. Reputasi, merupakan performa masa lalu dan sesuatu yang tak berwujud.

\section{Kerangka Pemikiran}

Kualitas produk merupakan pemahaman bahwa produk yang ditawarkan oleh penjual mempunyai nilai jual lebih yang tidak dimiliki oleh produk pesaing. Konsumen akan tertarik membeli suatu produk yang mempunyai kualitas yang baik, hal ini dapat dilihat dari kinerja, ciri khas, keandalan, ketahanan, daya guna, tanggapan, keindahan dan reputasi. Kualitas produk dari helem merek GM menentukan kepuasan konsumen dalam melakukan pembelian helm, ketika konsumen merasakan kepuasan setelah membeli produk tersebut hal ini berarti bahwa produk tersebut berkualitas.

Berdasarkan uraian di atas, maka dapat digambarkan suatu kerangka pemikiran, yang merupakan dasar penyusunan diafragma variabel-variabel yang dijadikan sasaran penelitian ini, sebagai berikut: 


\section{Kualitas produk}

$(\mathbf{x})$

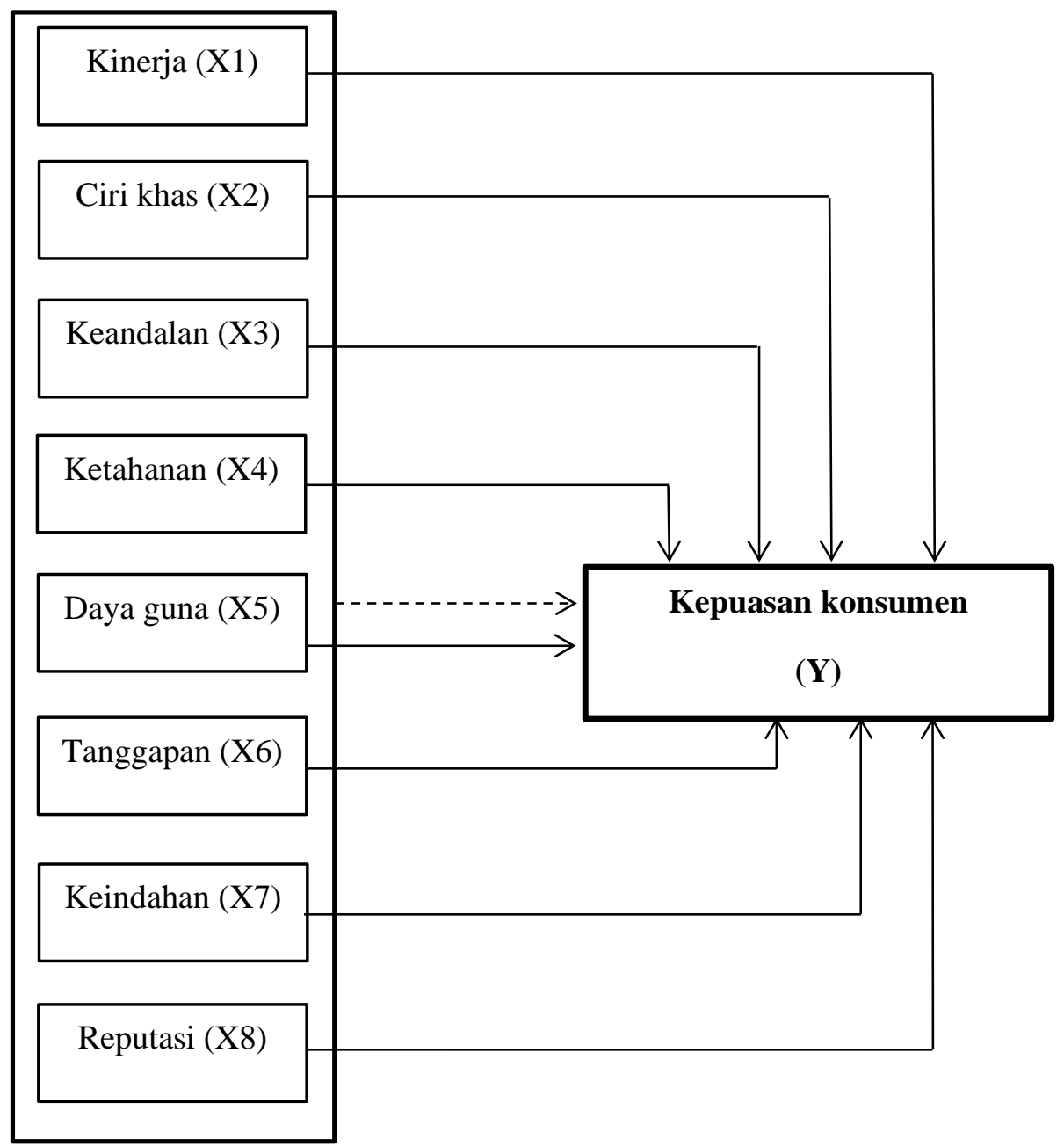

Gambar 1 Kerangka Pemikiran

Keterangan :

$$
\begin{aligned}
& \text { - - - Pengaruh Simultan } \\
& \longrightarrow=\text { Pengaruh Parsial }
\end{aligned}
$$

\section{METODE PENELITIAN}

Jenis penelitian yang digunakan adalah deskriptif kausal dan desain penelitian ini adalah deskriptif kausal, oleh karena penelitian ini berusaha menjabarkan hasil-hasil penelitian dari pengaruh variabel independen (X), yaitu kinerja, ciri khas, keandalan, ketahanan, daya guna, tanggapan, keindahan, dan reputasi (Y), yaitu kepuasan konsumen membeli helm merek GM di Kota Palu, metode pengumpulan data yang digunakan dalam penelitian ini terdiri dari:

a. Observasi

Observasi yaitu melakukan pengamatan secara langsung terhadap konsumen yang menggunakan helm GM di Kota Palu. 
Vol. 6, No.3, September 2020, 232-242

b. Wawancara

Yaitu melakukan tanya jawab langsung pada pihak-pihak yang bersangkutan (konsumen helm GM di Kota Palu) untuk mendapatkan data dan juga keterangan yang mendukung pelaksanaan penelitian ini.

c. Kuesioner

Yaitu teknik pengumpulan data dengan memberikan serangkaian pertanyaan yang diberikan pada pihak responden dalam hal ini adalah konsumen helm GM di Kota Palu. Data yang dihasilkan dari metode kuesioner ini akan menjadi data primer dan yang dihasilkan dari teknik pengumpulan data yang lain akan menjadi informasi tambahan.

d. Dokumentasi

Dokumentasi adalah mempelajari dasar-dasar teori maupun data praktis dari perpustakaan sehubungan dengan judul atau pokok bahasan yang diteliti dalam penelitian ini. Dalam melakukan dokumentasi, penulis menggunakan sarana perpustakaan dan teman untuk mendapatkan buku-buku atau teori-teori yang dibutuhkan.

Menurut Sugiyono (2016:115) "Populasi adalah wilayah generalisasi yang terdiri atas obyek dan subyek yang mempunyai kualitas dan karakteristik tertentu yang ditetapkan peneliti untuk dipelajari dan kemudian ditarik kesimpulannya”. Populasi dalam penelitian ini adalah seluruh konsumen yang membeli helm merek GM di Kota Palu.

Menurut Sugiyono (2016:119) sampel adalah bagian dari jumlah dan karakteristik yang dimiliki oleh populasi tersebut, populasi di atas yang menjelaskan bahwa jumlah populasi tidak diketahui secara pasti, maka dalam penelitian ini penarikan sampel dilakukan dengan menggunakan pendekatan yang dirujuk dari Sugiyono (2016:119) yang menyatakan bahwa untuk menentukan sampel dari populasi yang tidak diketahui adalah minimal 10 kali dari jumlah variabel yang diteliti. Berdasarkan pertimbangan tersebut, maka penulis menetapkan jumlah sampel dengan ketentuan 10 x 9 variabel, yaitu 90 responden, dengan demikian, sampel dari penelitian ini adalah 90 orang.

Metode analisis yang digunakan dalam penelitian ini adalah analisis regresi linear berganda. Analisis linear berganda digunakan untuk mengukur seberapa besarnya pengaruh variabel independen $(\mathrm{X})$ terhadap variabel dependen (Y). Adapun analisis regresi berganda diformulasikan dengan rumus:

$$
\mathrm{Y}=\alpha+\beta_{1} \mathrm{X}_{1}+\beta_{2} \mathrm{X}_{2}+\beta_{3} \mathrm{X}_{3}+\ldots+\beta_{\mathrm{k}} \mathrm{X}_{\mathrm{k}}+\mathrm{e}
$$

Keterangan:

$\begin{array}{ll}\mathrm{Y} & =\text { Variabel dependen } \\ \mathrm{X}_{1}-\mathrm{X}_{3} & =\text { Variabel independen } \\ \alpha & =\text { Konstanta } \\ \beta_{1}-\beta_{\mathrm{k}} & =\text { Koefisien Regresi } \\ \mathrm{e} & =\text { Error }\end{array}$

Berdasarkan model penelitian ini, maka akan terlihat sebagai berikut:

$\mathrm{Y}=\mathrm{a}+\mathrm{b} 1 \mathrm{X} 1+\mathrm{b} 2 \mathrm{X} 2+\mathrm{b} 3 \mathrm{X} 3+\mathrm{b} 4 \mathrm{X} 4+\mathrm{b} 5 \mathrm{X} 5+\mathrm{b} 6 \mathrm{X} 6+\mathrm{b} 7 \mathrm{X} 7+\mathrm{b} 8 \mathrm{X} 8+\mathrm{e}$

Dimana :

$\mathrm{Y}=$ Kepuasan Konsumen

$\mathrm{A}=$ Konstanta

b1 = Koefisien regresi variabel X1 (kinerja)

b2 $=$ Koefisien regresi variabel X2 (ciri khas)

b3 = Koefisien regresi variabel X3 (keandalan)

b4 = Koefisien regresi variabel X4 (ketahanan)

b5 = Koefisien regresi variabel X5 (daya guna)

b6 = Koefisien regresi variabel X6 (tanggapan)

b7 = Koefisien regresi variabel X7 (keindahan)

b8 $=$ Koefisien regresi variabel X8 (reputasi) 


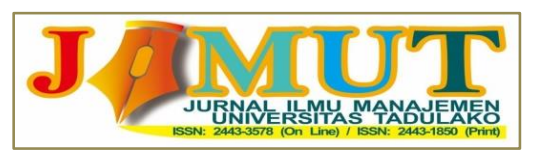

Vol. 6, No.3, September 2020, 232-242

$\mathrm{X} 1$ = kinerja

$\mathrm{X} 2=$ ciri khas

$\mathrm{X} 3=$ keandalan

$\mathrm{X} 4=$ ketahanan

$\mathrm{X} 5$ = daya guna

$\mathrm{X} 6=$ tanggapan

$\mathrm{X} 7=$ keindahan

$\mathrm{X} 8=$ reputasi

$\mathrm{e}=$ error $/$ variabel pengganggu

\section{HASIL DAN PEMBAHASAN}

Multikoliniearitas menunjukkan hubungan linier diantara variabel independen dalam model regresi, adanya multikolinearitas yang signifikan menyebabkan sulitnya untuk menaksir pengaruh variabel independen terhadap variabel dependen karena nilai standar error menjadi tidak terhingga. Untuk mengetahui adanya multikoliniearitas di antara variabel independen digunakan pendekatan pada nilai Tolerance dan Variance Inflation Factors (VIF). Tolerance yang semakin kecil atau mendekati 0 mengindikasikan terjadinya multikoliniearitas, bila nilai VIF $<10$ mengindikasikan bahwa model tidak terjadi multikolinearitas, tetapi bila VIF > 10 mengindikasikan bahwa dalam model terjadi multikolinearitas serius.

Hasil uji multikolinearitas menggunakan program SPSS For Windows Release 16.0 sebagai berikut:

Tabel 1 Hasil Uji Multikolinearitas

\begin{tabular}{|c|l|c|c|}
\hline No & \multicolumn{1}{|c|}{ Variabel } & Tolerance & VIF \\
\hline 1. & Kinerja & 0,729 & 1,372 \\
\hline 2. & Ciri khas & 0,845 & 1,184 \\
\hline 3. & Keandalan & 0,746 & 1,341 \\
\hline 4. & Ketahanan & 0,705 & 1,418 \\
\hline 5. & Daya guna & 0,655 & 1,527 \\
\hline 6. & Tanggapan & 0,655 & 1,527 \\
\hline 7. & Keindahan & 0,651 & 1,536 \\
\hline 8. & Reputasi & 0,763 & 1,311 \\
\hline
\end{tabular}

Sumber: data diolah, 2019

Hasil pengujian dalam tabel di atas menunjukkan bahwa nilai tolerance kedua variabel independen tidak mendekati nilai 0 dan nilai VIF $<10$. Hasil pengujian ini mengindikasikan bahwa dalam model regresi yang digunakan tidak terjadi multikolinearitas serius.

Cara mendeteksi adanya heterokedastisitas adalah dengan melihat penyebaran dari titik-titik (varians residual) melalui grafik scatterplot. Dasar pengambilan keputusannya adalah jika ada pola tertentu seperti titik-titik yang membentuk pola yang teratur maka mengindikasikan telah terjadi heterokedastisitas sedangkan jika tidak ada pola yang jelas dan titik-titik menyebar di atas dan di bawah angka 0 pada sumbu Y, maka tidak terjadi heterokedatisitas Ghozali (20013:105).

Grafik Scatterplot yang dihasilkan program SPSS For Windows Release 16.0 sebagai berikut: 


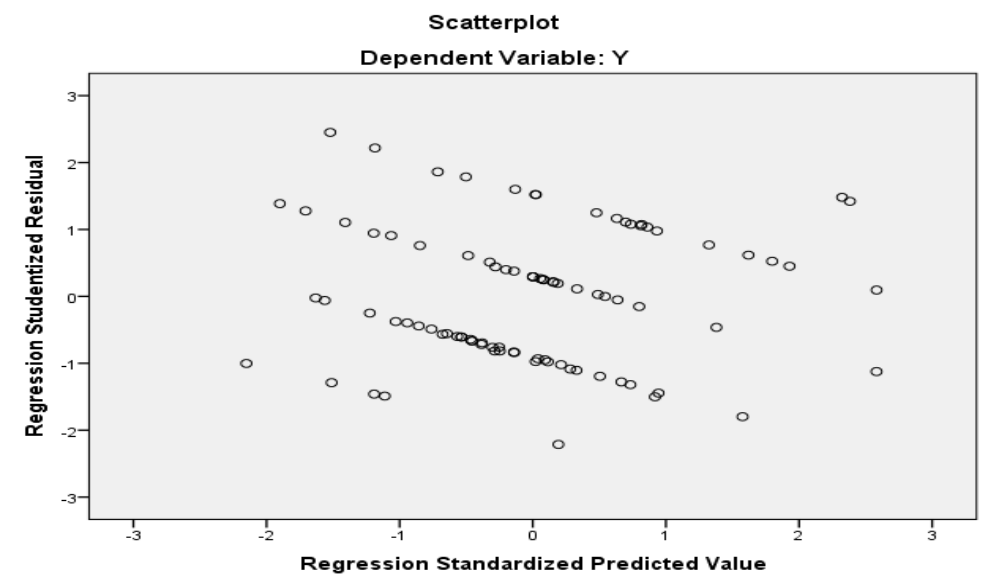

Sumber: data diolah, 2019

\section{Gambar 2 Hasil Uji Heterokedastisitas}

Gambar di atas menunjukkan bahwa titik-titik menyebar baik di atas maupun di bawah angka 0 pada sumbu Y. Hasil pengujian ini mengindikasikan bahwa tidak terjadi masalah heteroskedastisitas.

Pengujian normalitas data untuk mengetahui apakah data berdistribusi variabel normal atau tidak yang merupakan salah satu syarat penggunaan statistik parametrik, bila data setiap variabel tidak normal, maka pengujian hipotesis tidak bisa menggunakan statistik parametrik. Grafik probability plot (p-plot) yang dihasilkan program SPSS For Windows Release 16.0 sebagai berikut:

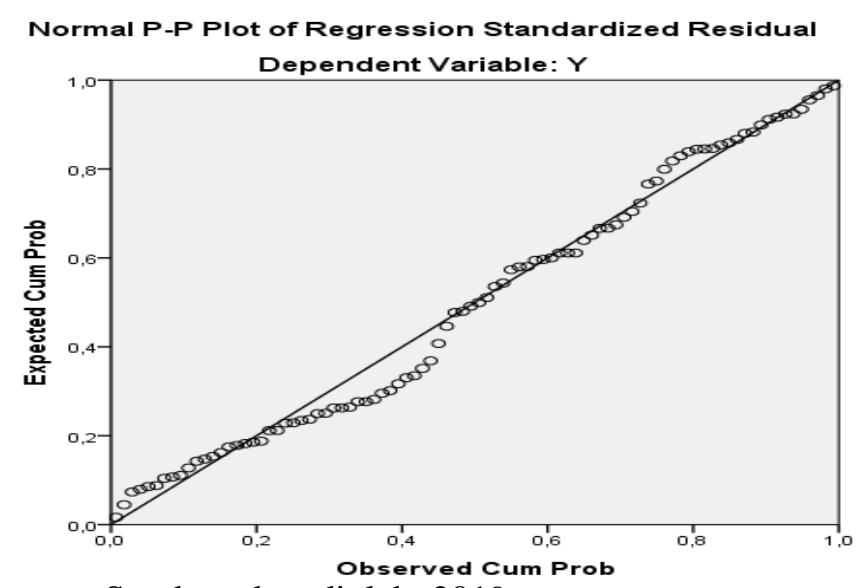

Sumber: data diolah, 2019

Gambar 3 Hasil Uji Normalitas

Grafik di atas menunjukkan bahwa titik-titik menyebar disekitar garis diagonal dan penyebarannya mengikuti garis diagonal, maka dapat disimpulkan bahwa model regresi memenuhi asumsi normalitas.

Analisis Regresi Linear Berganda berfungsi untuk mengukur pengaruh kualitas produk (X) yaitu kepuasan konsumen (Y). Hasil analisis Regresi Linear Berganda dengan menggunakan bantuan program Statistical Product and Service Solutions Release 16 for windows (SPSS 16) adalah sebagai berikut: 


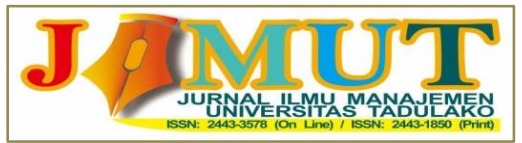

Vol. 6, No.3, September 2020, 232-242

Tabel 2 Hasil Analisis Regresi Linear Berganda

\begin{tabular}{|c|c|c|c|c|c|}
\hline No & Variabel & $\begin{array}{c}\text { Koefisien } \\
\text { Regresi } \\
\text { (Beta) }\end{array}$ & $\mathrm{T}$ & \multicolumn{2}{|c|}{ Probabilitas (Sig. t) } \\
\hline 1 & Constanta & 2,205 & & & \\
\hline 2 & Kinerja & 0,167 & 3,460 & \multicolumn{2}{|c|}{0,008} \\
\hline 3 & Ciri khas & 0,127 & 3,202 & \multicolumn{2}{|c|}{0,013} \\
\hline 4 & Keandalan & 0,047 & 2,415 & \multicolumn{2}{|c|}{0,039} \\
\hline 5 & Ketahanan & 0,067 & 2,575 & \multicolumn{2}{|c|}{0,027} \\
\hline 6 & Daya guna & 0,035 & 2,291 & \multicolumn{2}{|c|}{0,041} \\
\hline 7 & Tanggapan & 0,173 & 4,436 & \multicolumn{2}{|c|}{0,000} \\
\hline 8 & Keindahan & 0,234 & 4,940 & \multicolumn{2}{|c|}{0,000} \\
\hline 9 & Reputasi & 0,007 & 2,059 & \multicolumn{2}{|c|}{0,043} \\
\hline \multicolumn{2}{|c|}{ Multiple R $\quad=0,881$} & & & \multicolumn{2}{|c|}{ F-hitung $=53,046$} \\
\hline \multicolumn{2}{|c|}{ R. Square $\quad=0,776$} & & & \multirow{2}{*}{\multicolumn{2}{|c|}{$\begin{array}{ll}\text { F-tabel } & =2,00 \\
\text { t-tabel } & =1,66388\end{array}$}} \\
\hline \multicolumn{2}{|c|}{ Adjusted R. Square $=0,755$} & & & & \\
\hline A & $=0,05$ & & & \multicolumn{2}{|c|}{ Sig $\quad=0,000$} \\
\hline
\end{tabular}

Sumber: data diolah, 2019

Berdasarkan tabel di atas maka model persamaan Regresi Linear Berganda dalam penelitian ini adalah:

$Y=\mathbf{2 , 2 0 5}+\mathbf{0 , 1 6 7} \mathrm{X}_{1},+\mathbf{0 , 1 2 7} \mathrm{X}_{2}+\mathbf{0 , 0 4 7} \mathrm{X}_{3},+\mathbf{0 , 0 6 7} \mathrm{X}_{\mathbf{4}}+\mathbf{0 , 0 3 5} \mathrm{X}_{5},+\mathbf{0 , 1 7 3 X _ { 6 }}+\mathbf{0 , 2 3 4} \mathrm{X}_{7}+\mathbf{0 , 0 0 7} \mathrm{X}_{8}$

Model persamaan Regresi Linier Berganda di atas dapat dijelaskan sebagai berikut:

a. Nilai konstanta $a=2,205$ menunjukkan bila kinerja, ciri khas, keandalan, ketahanan, daya guna, tanggapan, keindahan, dan reputasi tidak berubah/konstan maka kepuasan konsumen adalah sebesar 2,205

b. Nilai koefisien regresi $b_{1}=0,167$ menunjukkan bahwa variabel kinerja $\left(\mathrm{X}_{1}\right)$ berpengaruh positif terhadap kepuasan konsumen, berarti bila kinerja ditingkatkan sedangkan ciri khas, keandalan, ketahanan, daya guna, tanggapan, keindahan, dan reputasi diasumsikan tidak berubah/konstan maka konsumen akan menjadi lebih puas.

c. Nilai koefisien regresi $b_{2}=0,127$ menunjukkan bahwa ciri khas $\left(\mathrm{X}_{2}\right)$ berpengaruh positif terhadap kepuasan konsumen, berarti bila ciri khas ditingkatkan sedangkan kinerja, keandalan, ketahanan, daya guna, tanggapan, keindahan, dan reputasi diasumsikan tidak berubah/konstan maka konsumen akan menjadi lebih puas.

d. Nilai koefisien regresi $b_{3}=0,047$ menunjukkan bahwa keandalan $\left(\mathrm{X}_{3}\right)$ berpengaruh positif terhadap kepuasan konsumen, berarti bila keandalan ditingkatkan sedangkan kinerja, ciri khas, ketahanan, daya guna, tanggapan, keindahan, dan reputasi diasumsikan tidak berubah/konstan maka konsumen akan menjadi lebih puas.

e. Nilai koefisien regresi $b_{4}=0,067$ menunjukkan bahwa ketahanan $\left(\mathrm{X}_{4}\right)$ berpengaruh positif terhadap kepuasan konsumen, berarti bila ketahanan ditingkatkan sedangkan kinerja, ciri khas, keandalan, daya guna, tanggapan, keindahan, dan reputasi diasumsikan tidak berubah/konstan maka konsumen akan menjadi lebih puas.

f. Nilai koefisien regresi $b_{5}=0,035$ menunjukkan bahwa daya guna $\left(X_{5}\right)$ berpengaruh positif terhadap kepuasan konsumen, berarti bila kinerja, ciri khas, keandalan, ketahanan, tanggapan, keindahan, dan reputasi diasumsikan tidak berubah/konstan maka konsumen akan menjadi lebih puas.

g. Nilai koefisien regresi $b_{6}=0,173$ menunjukkan bahwa tanggapan $\left(X_{6}\right)$ berpengaruh positif terhadap kepuasan konsumen, berarti bila kinerja, ciri khas, keandalan, ketahanan, daya guna, keindahan, dan reputasi diasumsikan tidak berubah/konstan maka konsumen akan menjadi lebih puas. 
Vol. 6, No.3, September 2020, 232-242

h. Nilai koefisien regresi $b_{7}=0,234$ menunjukkan bahwa keindahan $\left(X_{7}\right)$ berpengaruh positif terhadap kepuasan konsumen, berarti bila kinerja, ciri khas, keandalan, ketahanan, daya guna, tanggapan, dan reputasi diasumsikan tidak berubah/konstan maka konsumen akan menjadi lebih puas.

i. Nilai koefisien regresi $b_{8}=0,007$ menunjukkan bahwa reputasi $\left(\mathrm{X}_{8}\right)$ berpengaruh positif terhadap kepuasan konsumen, berarti bila kinerja, ciri khas, keandalan, ketahanan, daya guna, tanggapan, dan keindahan diasumsikan tidak berubah/konstan maka konsumen akan menjadi lebih puas.

Adapun tingkat keeratan hubungan antara variabel kinerja, ciri khas, keandalan, ketahanan, daya guna, tanggapan, keindahan, dan reputasi secara simultan dengan variabel kepuasan konsumen (Y) dapat dilihat nilai koefisien korelasi (Multiple $\mathrm{R}$ ), dari hasil analisis diperoleh nilai multiple $\mathrm{R}=0,881$ yang menunjukkan bahwa kinerja, ciri khas, keandalan, ketahanan, daya guna, tanggapan, keindahan, dan reputasi memiliki hubungan yang sangat kuat dengan kepuasan konsumen.

Untuk mengetahui pengaruh signifikan secara parsial ataupun simultan dari variabel independen (Kinerja $\left(\mathrm{X}_{1}\right)$, Ciri khas $\left(\mathrm{X}_{2}\right)$, Keandalan $\left(\mathrm{X}_{3}\right)$, Ketahanan $\left(\mathrm{X}_{4}\right)$, Daya guna $\left(\mathrm{X}_{5}\right)$, Tanggapan $\left(\mathrm{X}_{6}\right)$, Keindahan $\left(\mathrm{X}_{7}\right)$, dan Reputasi $\left(\mathrm{X}_{8}\right)$ terhadap Kepuasan konsumen $(\mathrm{Y})$, maka digunakan beberapa uji seperti uji $\mathrm{F}$ dan uji t.

Hasil penelitian ini membuktikan variabel kualitas produk yang terdiri dari kinerja, ciri khas, keandalan, ketahanan, daya guna, tanggapan, keindahan, dan reputasi berpengaruh secara simultan terhadap kepuasan konsumen membeli helm GM di Kota Palu.

Hasil penelitian ini membuktikan bahwa variabel kinerja, ciri khas, keandalan, ketahanan, daya guna, tanggapan, keindahan, dan reputasi secara parsial berpengaruh signifikan terhadap kepuasan konsumen dalam membeli helm GM di Kota Palu.

Menurut Kotler dan Keller, (2009: 354), kualitas produk adalah kemampuan suatu produk untuk melaksanakan fungsinya, yang meliputi daya tahan, kehandalan, ketepatan, kemudahan operasi dan perbaikan, serta atribut bernilai lainnya. Kualitas produk adalah kondisi yang berhubungan dengan fisik, sifat, kegunaaan suatu produk (barang atau jasa), yang dapat memenuhi kebutuhan dan keinginan konsumen. Jika kebutuhan dan keinginan konsumen sesuai dengan yang diharapkan maka konsumen akan memberikan kepuasan dalam membeli helm GM di Kota Palu. Hal ini sesuai dengan penelitian yang dilakukan oleh Soewito ( 2013) yang menyatakan bahwa kualitas produk berpengaruh signifikan terhadap kepuasan konsumen konsumen sepeda Motor Yamaha Mio.

Kemampuan produk berpengaruh dalam kepuasan konsumen membeli helm GM di Kota Palu. Kinerja suatu produk bisa memberikan kepuasan bagi konsumen yang menggunakan, maka kinerja suatu produk sangatlah penting untuk diperhatikan. Hal ini menujukkan bahwa kinerja mempengaruhi kepuasan konsumen membeli helm GM, ini berarti kinerja merupakan hal yang mempengaruhi kepuasan konsumen. Kinerja merupakan karakteristik operasi pokok dari produk inti (core product) yang dibeli kinerja dari produk yang memberikan manfaat bagi konsumen yang mengkonsumsi sehingga konsumen dapat memperoleh manfaat dari produk.

Konsumen akan selalu menyesuaikan ciri khas yang dimiliki produk dengan harga yang ditawarkan, ciri khas produk merupakan karakteristik sekunder atau pelengkap dari produk inti. Ciri khas yang ditawarkan juga dapat mempengaruhi tingkat kepuasan konsumen terhadap suatu produk. Keindahan merupakan daya tarik produk terhadap panca indra. Desain helm yang menarik akan meningkatkan rasa puas saat menggunakan helm GM, dengan demikian keindahan sebuah produk maka konsumen akan bangga menggunakan produk tersebut. 


\section{KESIMPULAN DAN SARAN}

\section{Kesimpulan}

1. Variabel kualitas produk (X) yang terdiri terdiri dari kinerja, ciri khas, keandalan, ketahanan, daya guna, tanggapan, keindahan, dan reputasi secara simultan berpengaruh signifikan terhadap kepuasan konsumen (Y) membeli helm GM di Kota Palu.

2. Kinerja berpengaruh signifikan terhadap kepuasan konsumen membeli helm GM di Kota Palu.

3. Ciri khas berpengaruh signifikan terhadap kepuasan konsumen membeli helm GM di Kota Palu.

4. Kehandalan berpengaruh signifikan terhadap kepuasan konsumen membeli helm GM di Kota Palu.

5. Ketahanan berpengaruh signifikan kepuasan konsumen membeli helm GM di Kota Palu.

6. Daya guna berpengaruh signifikan terhadap kepuasan konsumen membeli helm GM di Kota Palu.

7. Tanggapan berpengaruh signifikan terhadap kepuasan konsumen membeli helm GM di Kota Palu.

8. Keindahan berpengaruh signifikan terhadap kepuasan konsumen membeli helm GM di Kota Palu.

9. Reputasi berpengaruh signifikan terhadap kepuasan konsumen membeli helm GM di Kota Palu.

\section{Saran}

Adapun saran-saran untuk penelitian ini adalah sebagai berikut:

1. Sebaiknya kaca helm GM dibuat lebih tebal untuk melindungi mata pengguna.

2. Sebaiknya helm GM menambahkan karakter gambar yang lebih bervariasi.

3. Sebaiknya helm GM membuat desain helm yang lebih mewah untuk menarik perhatian konsumen.

4. Sebaiknya helm GM meningkatkan kualitas warna helm sehingga tidak mudah luntur.

5. Sebaiknya helm GM selalu menambah persediaan barang yang dijual.

6. Sebaiknya helm GM memproduksi helm dengan tampilan yang lebih menarik.

7. Untuk penelitian selanjutnya, dihaapkan untuk menambahkan variabel-variabel pembentuk kepuasan konsumen, agar hasil penelitiannya memberikan kontribusi yang bermakna pada pihak-pihak yang berkepentingan.

\section{REFERENSI}

Buchari Alma. 2014. Manajemen Pemasaran dan Pemasaran Jasa. Bandung: Alfabeta.

Ghozali, Imam. 2013. Aplikasi Analisis Multivariate dengan Program IBM SPSS 21 Update PLS Regresi. Semarang: Badan Penerbit Universitas Diponegoro.

Harman Malau, Ph. D. 2017. Manajemen Pemasaran. Bandung: Alfabeta.

Kotler dan Keller. 2009. Manajemen Pemasaran. Jilid 1. Edisi ke 13 Jakarta: Erlangga.

Kotler dan Keller. 2009. Manajemen Pemasaran. Jilid 2. Edisi ke 13 Jakarta: Erlangga.

Mariana (2015)."Pengaruh Kualitas Produk Dan Harga Terhadap Kepuasan konsumen Produk Pada Industri UKM Amplang UD. Sinar Rejeki Di Samarinda". eJournal Administrasi Bisnis, Volume 3, Nomor 2, 2015.

Ndaru Prasastono dan Sri Yulianto Fajar Pradapa (2012).'Kualitas Produk Dan Kualitas Pelayanan Terhadap Kepuasan Konsumen Kentucky Fried Chicken Semarang Candi”. Artikel Dinamika Kepariwisataan Vol. XI No. 2, Oktober 2012.

Sugiyono, 2016. Metode Penelitian Kuantitatif Kualitatif dan R\&D. Bandung : CV Alfabeta.

Sofjan Assuari,. 2004. Manajemen Pemasaran. Jakarta: Rajawali Press

Sistaningrum Widyaningtyas, 2002. Manajemen Penjualan Produk. Yogyakarta: Kanisius.

Shandy Widjoyo Putro dan Prof. Dr.Hatane Semuel, MS., Ritzky Karina M.R. Brahmana, S.E., M.A. (2014).’Pengaruh Kualitas Layanan Dan Kualitas Produk Terhadap Kepuasan Pelanggan Dan Loyalitas Konsumen Restoran Happy Garden Surabaya". Jurnal Manajemen Pemasaran Vol.2, No. 1, (2014). 


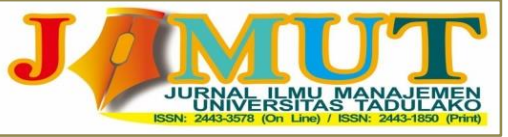

Vol. 6, No.3, September 2020, 232-242

Yudhi Soewito (2013) "Kualitas Produk, Merek Dan Desain Pengaruhnya Terhadap Kepuasan konsumen Sepeda Motor Yamaha Mio". Jurnal EMBA Vol.1 No.3 Juni 2013. 